Review

\title{
Formaldehyde Exposure and Epigenetic Effects: A Systematic Review
}

\author{
Veruscka Leso *(1), Maria Carmela Macrini, Francesco Russo and Ivo Iavicoli[i] \\ Department of Public Health, Section of Occupational Medicine, University of Naples Federico II, Via S. \\ Pansini 5, 80131 Naples, Italy; maria.carmela.macrini@hotmail.it (M.C.M.); francesco.russo.na@gmail.com (F.R.); \\ ivo.iavicoli@unina.it (I.I.) \\ * Correspondence: veruscka.leso@unina.it; Tel.: +39-081-746-4763; Fax: +39-081-746-2133
}

Received: 29 February 2020; Accepted: 24 March 2020; Published: 28 March 2020

\begin{abstract}
Formaldehyde (FA) is a general living and occupational pollutant, classified as carcinogenic for humans. Although genotoxicity is recognized as a FA mechanism of action, a potential contribution of epigenetic effects cannot be excluded. Therefore, aim of this review is to comprehensively assess possible epigenetic alterations induced by FA exposure in humans, animals, and cellular models. A systematic review of Pubmed, Scopus, and Isi Web of Science databases was performed. DNA global methylation changes were demonstrated in workers exposed to FA, and also in human bronchial cells. Histone alterations, i.e., the reduction in acetylation of histone lysine residues, in human lung cells were induced by FA. Moreover, a dysregulation of microRNA expression in human lung adenocarcinoma cells as well as in the nose, olfactory bulb and white blood cells of rodents and nonhuman primates was reported. Although preliminary, these findings suggest the role of epigenetic modifications as possible FA mechanisms of action that need deeper qualitative and quantitative investigation. This may allow to define the role of such alterations as indicators of early biological effect and the opportunity to include such information in future risk assessment and management strategies for public and occupationally FA-exposed populations.
\end{abstract}

Keywords: formaldehyde; epigenetic; DNA methylation; histone modifications; microRNAs; occupational exposure; biological monitoring; risk assessment; risk management

\section{Introduction}

Formaldehyde (FA) is a volatile, colorless, flammable, and highly reactive aldehyde, employed in the production of industrial and consumer products. It is present in both indoor and outdoor environments [1,2]. Indoor FA sources include building materials, such as furniture, particle board, certain insulation materials, paints, varnishes, and textiles [3,4]. Direct emissions from combustion processes occurring in motor vehicles, power plants, incinerators, refineries characterize a major anthropogenic source of FA in outdoor environments [5]. Certain workplaces, such as industries involved in resin, plastics, wood, insulation, paper, textile, and chemical productions, as well as medical institutions using disinfectants and embalming chemicals experience the highest levels of the substance [3]. Formaldehyde is also a by-product of cigarette smoke [3,6]. Additionally, it is found as a natural product in most living systems $[7,8]$.

Formaldehyde inhalation has been associated with sensory irritation of the eyes, and respiratory tract, childhood and adult asthma as well as to alterations in pulmonary function as reported in clinical studies and epidemiological surveys in occupational and residential environments [9]. The International Agency for Research on Cancer has classified FA as carcinogenic to humans (Group 1) because of its ability to cause cancer of the nasopharynx and leukemia and the detected positive association with sino-nasal cancer [3]. Great efforts have been focused on understanding the mode 
of action for FA carcinogenesis. Currently available data strongly indicate that genotoxicity plays an important role in the carcinogenicity of FA in humans. Numerous experiments have demonstrated that FA exposure can induce mutations in a variety of test systems ranging from bacteria to laboratory animals $[10,11]$. Moreover, micronucleus formation has been repeatedly reported to occur in cells of the nasal and oral mucosa of FA-exposed humans $[3,12,13]$. Formaldehyde is a highly reactive compound. It can covalently bind to DNA and proteins inducing adducts formation and cross-linking [8]. FA reacts with lysine residues to produce N(6)-formyl-lysine adducts with proteins in vitro and in vivo [14,15], and FA protein adducts have been described for albumin [16], insulin [17], and hemoglobin [18,19]. Such alterations may function as sensitive and specific exposure biomarkers (dose metric) and potential effect indicators, as they are involved in mutations and subsequent cancer development [20].

However, exposure to genotoxic carcinogens, in addition to their genetic effects, might involve a variety of non-genotoxic changes in cells [21]. In this perspective, it cannot be excluded that epigenetic mechanisms may contribute to the FA toxicity [22]. Epigenetics is defined as the study of heritable phenotypes that do not alter the DNA sequence, able to control development, tissue differentiation, and cellular responsiveness [23,24]. DNA methylation, post-translational histone modifications, and changes in microRNA expression are the most used mechanisms able to initiate and sustain epigenetic information. These effects may all contribute to regulate gene expression profiles, affecting chromatin structure, chromosome integrity, gene transcription, and genomic imprinting therefore possibly contributing to the risk of disease development [25]. An altered epigenetic status may cause genomic instability and loss of controlled growth signals, as typically observed in cancer cells [26]. Epigenetic alterations, rather than specific genetic mutations per se are reported for the clonal expansion of altered preneoplastic foci and tumor development [27]. Therefore, it seems important to verify if epigenetic modifications may function as early cellular events in response to genotoxic carcinogens with well-known modes of action.

Considering the ubiquitous nature of FA pollutant and the great number of job categories potentially exposed in workplaces, the aim of our review is to provide a comprehensive overview on possible epigenetic changes induced by FA exposure in humans, animals, and cellular models and to address the potential health impact derived from such effects. This may allow to deeply understand the molecular mechanisms underlying FA-induced toxicity and carcinogenicity and to define novel, early biological alterations that may function as possible future biomarkers of effect or susceptibility in exposed subjects. Overall, this review may provide deep insight into the relationship between genome, FA chemical exposure, and disease risk and may be helpful to point out biological mechanisms that should be carefully considered in future public and occupational risk assessment and management approaches.

\section{Materials and Methods}

According to the Preferred Reporting Items for Systematic Reviews and Meta-Analyses Statement (PRISMA) criteria [11], a systematic literature search was performed on PubMed, Scopus, and ISI Web of Science databases. The search aimed to identify studies focusing on epigenetic effects induced by formaldehyde exposure published until the 1st of November 2019 (Figure 1). The terms "formaldehyde," "exposure," "epigenetic," combined with the Boolean operator "AND," were employed to assess the exposure context and the outcome of the investigation. All titles and abstracts retrieved were independently examined by two of the authors who selected articles that met the inclusion criteria. Peer-reviewed research articles, i.e., cross-sectional, cohort, case-control studies, published in English and exploring epigenetic alterations determined by FA exposure in humans have been included together with studies performed on animal and cellular models. Exclusion criteria regarded articles published in languages other than English, papers exploring epigenetic effects of endogenous FA, studies carried out on experimental models different from cells, animals and human subjects, review and conference papers, as well as publications not addressing the possible relationship between FA exposure and epigenetic effects. Our preliminary search retrieved 13, 25, and 15 references through 
PubMed, Scopus, and ISI Web of Science databases, respectively, for a total of 53 articles. After duplicate removal, 29 articles remained. Among those, the studies that did not meet the inclusion criteria were excluded and specifically, 17 were removed because they were considered out of the topic from title and abstract analysis, 5 were excluded as review articles, and 1 as performed in experimental settings different from those considered suitable for inclusion. Indeed, 6 publications could be identified in this preliminary phase. Therefore, an extended search, including the following terms: "formaldehyde exposure," individually combined with "DNA methylation," "histone," and "microRNA," was performed and could retrieve the above mentioned papers. Four further eligible articles could be included through the assessment of the reference list accompanying published articles and implement the pool of relevant publications found via the electronic search. All full texts of the articles considered valuable for the aim of our review have been obtained and a critical evaluation was performed. Overall, our search retrieved a total of 10 publications for review.

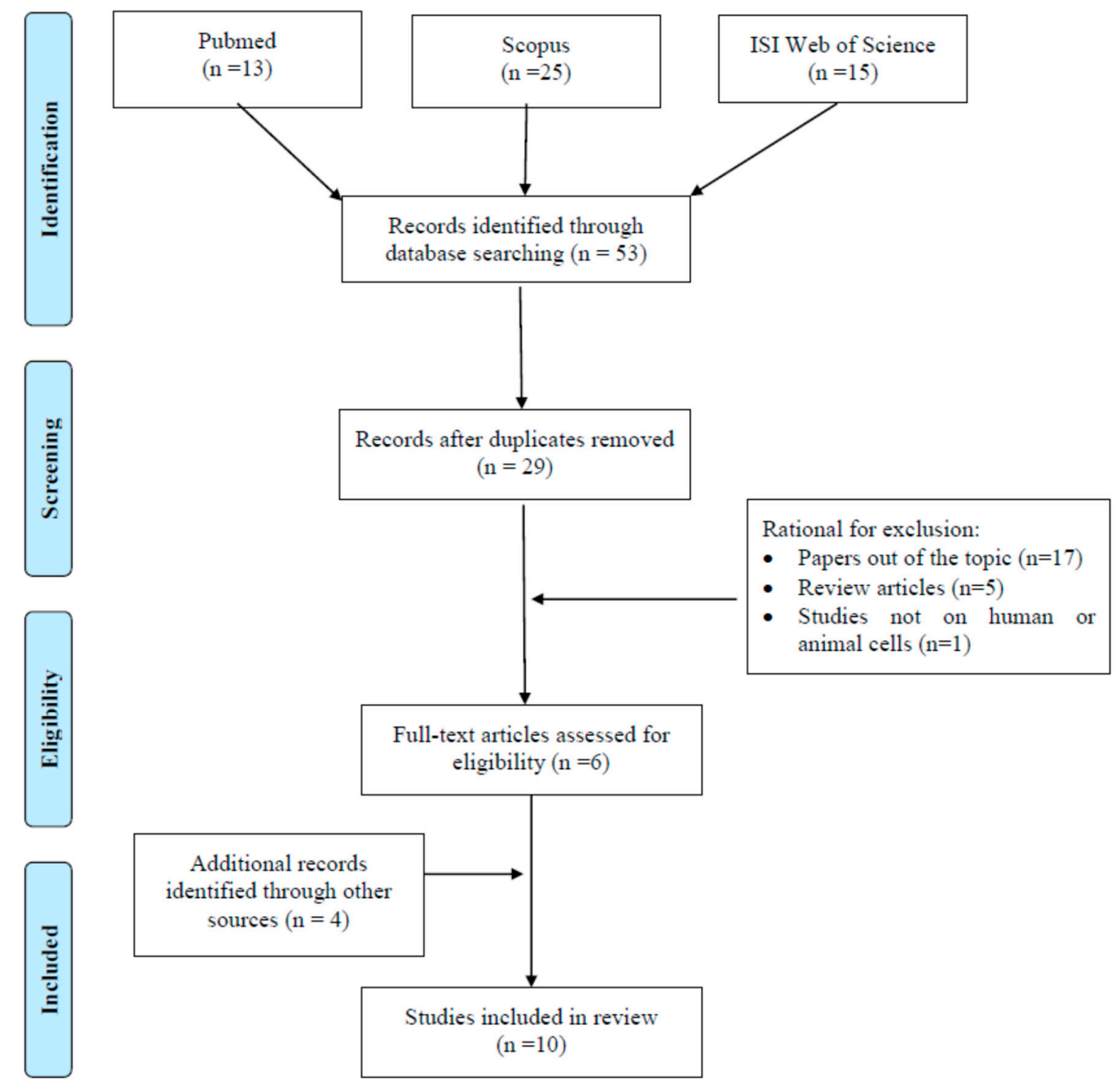

Figure 1. Flow diagram of literature search.

\section{Formaldehyde-Induced Epigenetic Effects}

Formaldehyde-induced epigenetic changes, such as DNA methylation [21,28,29], histone modifications [30-32], as well as alterations in non-coding microRNAs (MiRNAs) [33-36] have been investigated both in occupational and experimental settings (Table 1). The following paragraphs will attempt to summarize such effects with the aim to point out currently available data and critical issues that require further epidemiological research in order to also conceive epigenetic contribution to risk assessment and management strategies. 
Table 1. Studies addressing epigenetic formaldehyde (FA) effects in humans, animals, and cellular models.

\begin{tabular}{|c|c|c|c|c|}
\hline $\begin{array}{l}\text { EXPERIMENTAL } \\
\text { SETTING }\end{array}$ & $\begin{array}{l}\text { EPIGENETIC } \\
\text { OUTCOMES }\end{array}$ & EXPERIMENTAL DESIGN & MAIN RESULTS & REFERENCES \\
\hline \multicolumn{5}{|c|}{ HUMAN INVESTIGATION } \\
\hline $\begin{array}{l}\text { Brazilian hairdressers, } \\
\text { hairdresser assistants, } \\
\text { receptionists, manicurists, } \\
\text { and managers (n. } 41 \mathrm{~F} ; 8 \mathrm{M}) \\
\text { Mean age } \pm \text { SD: } 31.04 \pm \\
10.46 \text { years } \\
\text { Years working in beauty } \\
\text { salons (median: } 6 \text { years) } \\
\text { No unexposed controls } \\
\text { were enrolled. }\end{array}$ & DNA Methylation & $\begin{array}{l}\text { Airborne FA concentrations were } \\
\text { measured through personal (samplers } \\
\text { fitted in volunteers breathing zone) and } \\
\text { area passive samplers ( } 8 \text {-h work shift). } \\
\text { Global DNA methylation was assessed } \\
\text { in whole blood samples were collected } \\
\text { after 8-h of work. } \\
\text { Biological monitoring of formic acid } \\
\text { was performed on urine samples } \\
\text { collected at the beginning of the work } \\
\text { shift and again } 8 \mathrm{~h} \text { after the first } \\
\text { sampling. }\end{array}$ & $\begin{array}{l}\text { Median personal FA environmental exposure (ppm): } \\
\text { group A (n. 8): 0.013; group B (n. 15): 0.035; group C } \\
\text { (n. 26): 0.07. } \\
\text { Median biological monitoring levels of formic acid } \\
\text { before exposure (mg/L): group A: } 25.99 \text {; group B: } \\
\text { 24.80; group C: 19.93. Median biological monitoring } \\
\text { levels of formic acid after exposure (mg/L): group A: } \\
\text { 21.49; group B: 20.70; group C: } 22.44 \text {. } \\
\text { Higher median levels of global DNA methylation } \\
\text { were determined in groups B (4.55\%) and C (4.29\%) } \\
\text { compared to group A (3.12\%). } \\
\text { Statistically significant positive correlation was } \\
\text { found between global DNA methylation and FA in } \\
\text { the personal passive samplers (rs: 0.307, p: 0.032). } \\
\text { No significant increase in biological monitoring } \\
\text { findings could be observed between the 3 groups. }\end{array}$ & Barbosa et al. [28] \\
\hline \multicolumn{5}{|c|}{ IN VIVO EXPERIMENTS } \\
\hline Male Fischer rats & MicroRNAs & $\begin{array}{l}\text { Nose-only exposure to } 2 \mathrm{ppm} \\
\text { formaldehyde for } 6 \mathrm{~h} / \text { day; Four groups } \\
\text { of exposure were considered: } 7,28,28 \\
\text { days plus a } 7 \text {-day recovery period, } \\
\text { unexposed controls. } \\
\text { Multiple samples were collected from } \\
\text { the nasal epithelium, circulating } \\
\text { mononuclear WBCs, and BM cells. } \\
\text { Microarray analysis employed to assess } \\
695 \text { rat known miRNAs. }\end{array}$ & $\begin{array}{l}\checkmark \text { FA exposure affected the expression levels of } 108 \\
\text { miRNAs in nose samples, specifically, } 84,59 \text {, and } 0 \\
\text { miRNAs altered in the } 7,2 \text {, and } 28 \text {-day plus } 7 \\
\text { day-recovery groups, respectively. } \\
\text { In the WBCs, FA exposure altered the expression of } \\
40 \text { miRNAs: } 31,8 \text {, and } 3 \text { miRNAs at the } 3 \text { different } \\
\text { time points, respectively. In BM, no changes in } \\
\text { miRNAs were identified. } \\
\checkmark \text { Transcriptomics based analysis demonstrated that } \\
\text { FA exposure induced differential expression of } 830 \\
\text { and } 42 \text { genes in the nose and in } 96 \text { and } 130 \text { genes in } \\
\text { WBC, in the } 7 \text { and } 28 \text { day group, respectively. } \\
\text { Thirty-five of the } 864 \text { total FA responsive transcript } \\
\text { are immune cell specific. Seven transcripts showed } \\
\text { formaldehyde-induced expression in both exposure } \\
\text { groups, namely Cd34, Clec7a, Fcgr2b, Lpl, Lsp1, } \\
\text { Mustn1, and Osmr. }\end{array}$ & Rager et al. [34] \\
\hline
\end{tabular}


Table 1. Cont

\begin{tabular}{|c|c|c|c|c|}
\hline $\begin{array}{l}\text { EXPERIMENTAL } \\
\text { SETTING }\end{array}$ & $\begin{array}{l}\text { EPIGENETIC } \\
\text { OUTCOMES }\end{array}$ & EXPERIMENTAL DESIGN & MAIN RESULTS & REFERENCES \\
\hline ICR male mice & MicroRNAs & $\begin{array}{l}\text { Mice treated with } 3 \text { ppm FA for } 6 \mathrm{~h} \text { for } \\
\text { either } 1 \text { or } 7 \text { consecutive days via } \\
\text { inhalation; controls maintained in the } \\
\text { same conditions except for FA. } \\
\text { Olfactory bulb homogenized and RNA } \\
\text { isolated for microarray analysis. } \\
\text { Expression levels of miRNAs tested } \\
\text { using quantitative RT-PCR. }\end{array}$ & $\begin{array}{l}\text { Microarray analysis: } 18 \text { and } 7 \text { miRNAs were up- and } \\
\text { downregulated, respectively, after exposure to } 3 \\
\text { ppm for } 6 \text { h. greatest increase reported for } \\
\text { miR-199b-5p and miR-144-5p. Exposure for } 7 \text { days } \\
\text { only altered the expression of nine miRNAs: eight } \\
\text { increased and one decreased. } \\
\text { miRNAs (mir-144-5p, miR-199b-5p, miR-200a-5p } \\
\text { and miR-146b-5p) increased most after } 6 \text { h/1-day and } \\
6 \text { h/7 days of FA exposures confirmed by RT-PCR. } \\
\text { A total of } 295 \text { genes predicted to be regulated by } \\
\text { miR-199b-5p, } 247 \text { by miR-200a-5p and } 139 \text { by } \\
\text { miR-146b-5p. pathways with the highest scores } \\
\text { were the integrin signaling pathway and the axonal } \\
\text { guidance signaling pathway. }\end{array}$ & Li et al. [35] \\
\hline $\begin{array}{l}\text { Male cynomolgus } \\
\text { macaques (Macaca } \\
\text { fascicularis, n. } 8 \text { ) }\end{array}$ & MicroRNAs & $\begin{array}{l}\text { Animals exposed via inhalation to } 0,2 \text {, } \\
\text { or } 6 \text { ppm FA for } 6 \mathrm{hr} / \text { day for two } \\
\text { consecutive days. } \\
\text { Small RNAs extracted from nasal } \\
\text { samples, collected within } 3 \mathrm{~h} \text { from the } \\
\text { last exposure, assessed for } \\
\text { genome-wide miRNA expression levels. } \\
\text { Transcriptional targets of FA-affected } \\
\text { miRNAs analyzed. Expression levels of } \\
\text { miRNAs tested using quantitative } \\
\text { RT-PCR. }\end{array}$ & $\begin{array}{l}\checkmark \text { FA exposure significantly decreased the expression } \\
\text { levels of } 3 \text { miRNA following } 2 \text { ppm and disrupted } \\
\text { the expression of } 13 \text { miRNAs following } 6 \text { ppm. } \\
\checkmark \text { Three miRNAs that were significantly decreased in } \\
\text { response to } 2 \text { ppm FA (i.e., miR-142-3p, miR-145, } \\
\text { and miR-203) were also significantly decreased in } \\
\text { response to } 6 \text { ppm FA. } \\
\text { Pathways of highest significance correlated with } \\
\text { increased expression of miR-125b was the apoptosis } \\
\text { signaling (expression levels of apoptotic related } \\
\text { genes, i.e., BAK1, CASP2, MAP2K7, MCL1 were } \\
\text { significantly reduced) }\end{array}$ & Rager et al. [36] \\
\hline
\end{tabular}


Table 1. Cont

\begin{tabular}{|c|c|c|c|c|c|}
\hline $\begin{array}{l}\text { EXPERIMENTAL } \\
\text { SETTING }\end{array}$ & $\begin{array}{l}\text { EPIGENETIC } \\
\text { OUTCOMES }\end{array}$ & EXPERIMENTAL DESIGN & & MAIN RESULTS & REFERENCES \\
\hline \multicolumn{6}{|c|}{ IN VITRO EXPERIMENTS } \\
\hline $\begin{array}{l}\text { Human bronchial } \\
\text { epithelial (16HBE) cells }\end{array}$ & DNA methylation & $\begin{array}{l}\text { Cell cultures treated with } 10 \text { mM FA for } \\
24 \mathrm{~h} \text { for } 24 \text { weeks. Control cells treated } \\
\text { with serum-free MEM. } \\
\text { BTC, a malignant transformed } 16 \mathrm{HBE} \\
\text { cell line was used as a positive control. } \\
\text { Genomic DNA methylation measured } \\
\text { by: anti-5-methyl-C immuno- } \\
\text { histochemistry assay, flow cytometric } \\
\text { assay and HPCE assay. }\end{array}$ & $\checkmark$ & $\begin{array}{l}\text { Genome of treated cells undergo a gradually global } \\
\text { hypomethylation with increasing exposure time } \\
\text { to FA: - Anti-5-methyl-C immunohistochemistry } \\
\text { assay: mean density of fluorescence was reduced to } \\
32.1 \text { following } 24 \text { weeks of treatment, for control } \\
\text { group the density was } 61.3 \text {, after } 6 \text { weeks } 54.4 \text {, after } \\
12 \text { weeks } 43.5 \text { and for BTC groups } 43.5 \text {; - Flow } \\
\text { cytometric assay: fluorescence intensity of } 16 \mathrm{HBE} \\
\text { cells was reduced to } 36.1 \text { at } 24 \text { weeks of treatment, } \\
\text { while was } 76.5 \text { for control, } 62.4 \text { after } 6 \text { weeks, } 45.2 \\
\text { after } 12 \text { weeks and } 34.9 \text { for BTC; - HPCE assay: an } \\
\text { average proportion of methylated mC/(C + mC) was } \\
4.72 \% \text { in control, } 3.76 \% \text { in } 6 \text { week, } 3.22 \% \text { in } 12 \text { week } \\
\text { and } 2.35 \% \text { in } 24 \text { week groups, while } 2.1 \% \text { in } \\
\text { BTC group. } \\
\text { The mRNA expression level for DNMT3a and } \\
\text { DNMT3b significantly and gradually decreased, } \\
\text { while that of DNMT1 and MBD2 significantly } \\
\text { increased gradually with increasing exposure time } \\
\text { to FA. }\end{array}$ & Liu et al. [29] \\
\hline $\begin{array}{l}\text { Human lymphoblastoid } \\
\text { cells (TK6) }\end{array}$ & DNA methylation & $\begin{array}{l}\text { Cells were exposed to } 3 \text { concentrations } \\
\text { of FA ( } 95 \% \text { cellular viability- high dose; } \\
1 / 10 \text { of high dose: medium dose; } 1 / 100 \\
\text { of high dose: low dose) for } 24 \text { h with or } \\
\text { without a mix of S9 metabolic mix } \\
\text { required for biotransformation of } \\
\text { procarcinogens into active carcinogens. } \\
\text { Global DNA methylation was obtained } \\
\text { quantifying ( } 5 \mathrm{Me} \text { )dC and dC using } \\
\text { ultrapressure liquid chromatography } \\
\text { for separation and tandem mass } \\
\text { spectrometry for quantification. }\end{array}$ & $\checkmark$ & $\begin{array}{l}\text { No significant DNA methylation changes were } \\
\text { detected in response to FA exposure to } \\
\text { diverse concentrations. } \\
\text { Global mean } \pm \text { SD percentages of DNA methylation } \\
\text { were: } 4.09 \pm 0.23 ; 5.21 \pm 0.57 \text { and } 4.61 \pm 0.23 \text { in low, } \\
\text { medium and high dose, respectively, in absence of } \\
\text { S9 metabolic mix } \\
\text { Global mean } \pm \text { SD percentages of DNA methylation } \\
\text { were: } 4.61 \pm 0.44 ; 4.55 \pm 0.43 \text { and } 4.23 \text { and in low, } \\
\text { medium and high dose, respectively, in the presence } \\
\text { of S9 metabolic mix. }\end{array}$ & Tabish et al. [21] \\
\hline
\end{tabular}


Table 1. Cont

\begin{tabular}{|c|c|c|c|c|c|}
\hline $\begin{array}{l}\text { EXPERIMENTAL } \\
\text { SETTING }\end{array}$ & $\begin{array}{l}\text { EPIGENETIC } \\
\text { OUTCOMES }\end{array}$ & EXPERIMENTAL DESIGN & & MAIN RESULTS & REFERENCES \\
\hline $\begin{array}{l}\text { Human lung } \\
\text { adenocarcinoma epithelial } \\
\text { (A549) cells }\end{array}$ & Histone Modifications & $\begin{array}{l}\text { Cell cultures treated with } 0-1 \text { mM FA for } \\
10-600 \text { min } \\
\text { Western blotting employed to determine } \\
\text { histone modifications. }\end{array}$ & $\checkmark$ & $\begin{array}{l}\text { FA increased the phosphorylation of H3S10, and } \\
\text { H3S28 and gamma-H2AX with generation peaks } \\
60-240 \text { min after the treatment. } \\
\text { FA-induced phosphorylation of H3S10 in a } \\
\text { concentration dependent manner up to } 1 \mathrm{mM} \text {. } \\
\text { Conversely phosphorylation decreased from } 3 \\
\text { mM FA. } \\
\text { FA decreased the acetylation of histone H3 at lysine } \\
9 \text { (H3K9), at lysine } 14 \text { (H3K14), and at the } \\
\text { N-terminal site (H3 global). Phosphorylation of } \\
\text { H3S10 plays an important role in the induction of } \\
\text { immediate-early genes, such as c-fos and c-jun. The } \\
\text { treatment with FA significantly induced both genes } \\
\text { in a dose-dependent manner. }\end{array}$ & Yoshida et al. [30] \\
\hline $\begin{array}{l}\text { Human bronchial } \\
\text { epithelial BEAS-2B cells; } \\
\text { human osteosarcoma } \\
\text { UTA6 cells; human nasal } \\
\text { septum quasidiploid } \\
\text { tumor RPMI2650 cells }\end{array}$ & Histone Modifications & $\begin{array}{l}\text { Cell cultures treated with } 0-0.5 \mathrm{mM} \text { FA } \\
\text { for } 6 \mathrm{~h} \text {. For chronic FA } 0-0.1 \mathrm{mM} \text { for } 96 \mathrm{~h} \text {. } \\
\text { Protein carbonyl assays employed to } \\
\text { determine FA adducts with histone } \\
\text { proteins } \\
\text { Histone post-transcriptional } \\
\text { modifications assessed by Western blot } \\
\text { analysis. }\end{array}$ & $\checkmark$ & $\begin{array}{l}\text { FA exposure induced a significant reduction in the } \\
\text { acetylation of the N-terminal tails of cytosolic } \\
\text { histones (H3K9Ac, H3K14Ac, H4K12Ac) of BEAS-2B } \\
\text { cells. Levels of H4K12Ac were significantly reduced } \\
\text { in all } 3 \text { cell lines following } 100 \mu \mathrm{M} \text { FA for } 24-72 \mathrm{~h} \text {. }\end{array}$ & Chen et al. [31] \\
\hline $\begin{array}{l}\text { Human lung } \\
\text { adenocarcinoma epithelial } \\
\text { (A549) cells; normal } \\
\text { human lung fibroblasts, } \\
\text { MRC-5 and WI-38 }\end{array}$ & Histone Modifications & $\begin{array}{l}\text { Cells were treated with various } \\
\text { concentrations of cigarette side-stream } \\
\text { smoke }(\sim 6.25 \%-100 \%) \text { for } \sim \text { up to } 8 \mathrm{~h} \text {. } \\
\text { Flow cytometric analysis was performed } \\
\text { to assess phosphor-H3S10 }\end{array}$ & $\checkmark$ & $\begin{array}{l}\text { Cigarette side-stream smoke induced a marked, } \\
\text { dose-dependent phosphorylation of H3S10 and } \\
\text { H3S28 in all } 3 \text { cellular models. } \\
\text { The phosphorylation increased up to } 60 \text { min and } \\
\text { gradually decreased from } 120 \text { min. } \\
\text { Acetylation of H3K9 and H3K14 slightly increased } \\
\text { at } 60-180 \mathrm{~min} \text { and } 120-360 \mathrm{~min} \text {, respectively. }\end{array}$ & Ibuki et al. [32] \\
\hline
\end{tabular}


Table 1. Cont.

\begin{tabular}{|c|c|c|c|c|c|}
\hline $\begin{array}{l}\text { EXPERIMENTAL } \\
\text { SETTING }\end{array}$ & $\begin{array}{l}\text { EPIGENETIC } \\
\text { OUTCOMES }\end{array}$ & EXPERIMENTAL DESIGN & & MAIN RESULTS & REFERENCES \\
\hline $\begin{array}{l}\text { Human lung } \\
\text { adenocarcinoma epithelial } \\
\text { (A549) cells }\end{array}$ & MicroRNAs & $\begin{array}{l}\text { Cell cultures treated with } 1 \mathrm{ppm}(1.2 \\
\left.\mathrm{mg} / \mathrm{m}^{3}\right) \text { gaseous FA generated by heat } \\
\text { in } 143 \mathrm{mg} \text { paraformaldehyde until } \\
\text { powder completely vaporized. } \\
\text { Microarray analysis employed to assess } \\
>500 \text { known miRNAs. } \\
\text { Expression levels of miRNAs also } \\
\text { tested using quantitative RT-PCR. }\end{array}$ & $\begin{array}{l}\checkmark \\
\checkmark\end{array}$ & $\begin{array}{l}\text { The most significantly differentially expressed } \\
\text { miRNAs were miR-33 }(\mathrm{FC}=-5.5), \mathrm{miR}-450(\mathrm{FC}= \\
-3.6), \text { miR-330 }(\mathrm{FC}=-2.4), \text { miR-181a }(\mathrm{FC}=-2.1) \text {, } \\
\text { and miR-10b }(\mathrm{FC}=-2.1) \text {. } \\
\text { qRT-PCR validated the findings of the decreased } \\
\text { miRNA expression induced by formaldehyde } \\
\text { exposure: } \mathrm{FC}=-1.3 \text { for miR-330; } \mathrm{FC}=-7.4 \text { for } \\
\text { miR-181a; FC }=-1.2 \text { for miR-33; and FC }=-1.5 \\
\text { for miR-10b. } \\
\text { Signaling pathways associated with cancer, } \\
\text { inflammatory response, and endocrine system } \\
\text { regulation related to miRNA expression alterations. }\end{array}$ & Rager et al. [33] \\
\hline
\end{tabular}




\subsection{DNA Methylation}

DNA methylation is a major epigenetic modification in mammals [29,37]. It involves the addition of a methyl group to the cytosine nucleotide at $\mathrm{CpG}$ sites via the donation from S-adenosylmethionine, catalyzed by DNA methyltransferases (DNMTs) [37]. DNA methylation can affect the chromatin structure, and therefore, control the selective transcription or silencing of tissue-specific genes potentially involved in disease pathogenesis [29]. The possible effects of occupational exposure to FA on global DNA methylation were investigated in a population of Brazilian beauty salon workers [28]. These were exposed during hair treatments employing creams illegally added with FA as a straightening agent. Environmental monitoring allowed to rank workers into three increasing groups (A, B, C) of exposure according to the FA environmental workplace levels: $<0.01 \mathrm{ppm} ; 0.03 \mathrm{ppm}<\mathrm{FA}<0.06 \mathrm{ppm}$; and $0.08 \mathrm{ppm}<\mathrm{FA}<0.24 \mathrm{ppm}$. Interestingly, significantly higher levels of global DNA methylation were detected in the whole blood samples from the two groups with the highest environmental exposures in comparison to the group with the lowest one, but not between each other. A weak, but significant correlation was also found between global DNA methylation and FA in personal exposure sampling. Furthermore, methylation changes were positively associated with the number of straightening procedures carried out per month. In this latter regard, to better define the possible dose-response relationships, the hairdressers from the two groups with the highest levels of exposure were further divided depending on whether they were directly involved in hair straightening procedures or not. A significant increase in FA personal exposure levels (median values: $0.19 \mathrm{ppm}$ vs. $0.041 \mathrm{ppm}$ ), and percentages of global DNA methylation $(4.63 \%$ vs. $4.29 \%)$ was determined in the directly exposed group compared to the other one. This may suggest that the proximity these workers experienced to the source of contamination may play a significant role in affecting exposure levels and biological responses [12,38]. Interestingly, these epigenetic changes were detected at exposure levels lower than occupational limits proposed by different agencies in Brazil [39], by the USA Occupational Safety and Health Administration [40], and by the European Chemical Agency [41] supporting their role as early biological effect indicators in response to chemical insults. Unfortunately, no other data are currently available on occupational or general living FA exposure and DNA methylation changes for comparison and therefore, caution is necessary for a correct interpretation of the results and the extrapolation of biological monitoring conclusions.

An in vitro study reported a time-dependent decrease in global DNA methylation following chronic (24 weeks), low-dose FA exposure of 16 human bronchial epithelial (16HBE) cells compared to controls [29]. The expression of DNA methyltransferases (DNMTs), as the enzymes responsible for maintaining the methylation status in the genome, was tested both at mRNA and protein level to define the initial mechanisms of global genomic hypomethylation induced by FA. Also, the expression of the methyl-CpG-binding protein DNA-binding domain protein 2 (MBD2), responsible for binding methylated DNA to suppress transcription from a methylated gene was investigated. A significant reduction in the expression of DNMT3a and DNMT3b was detected with the increasing exposure time to FA, while that of DNMT1 and MBD2 time-dependently increased. The loss of global DNA methylation, an epigenetic alteration associated with genomic instability, after long term exposure to a low-dose, may be one of the possible underlying carcinogenic mechanisms of FA. Moreover, it cannot be excluded that the different DNMT expression responses may be related to their diverse role in DNA methylation. In fact, DNMT3a and DNMT3b are primarily involved in establishing a new methylation pattern to unmodified DNA, while the DNMT1 functions during DNA replication to copy methylation pattern from the parental DNA strand to the newly synthesized daughter strand [42]. This may suggest the existence of specific FA-induced enzymatic responses which, in turn, may lead to i.e., genomic instability, aberrant expression of genes, as well as carcinogenesis, although their exact mechanisms require further research.

Another study carried out on human lymphobastoid TK6 cells failed to confirm previous data, reporting no significant global DNA methylation changes following acute exposure to increasing FA concentrations [21]. However, the different experimental settings employed in such studies may be 
responsible for the diverse obtained findings and further investigations are warranted to confirm such epigenetic effects and define the FA impact on DNA methylation.

\subsection{Histone Modifications}

Histone modifications occur post-transcriptionally and can affect the accessibility of DNA to transcription factors or DNA damaging agents, thus influencing DNA transcription, damage, and repair [43]. There are several types of histone modifications, including methylation, acetylation, phosphorylation, and ubiquitination of specific amino acid residues on the histone tails [44]. These molecular changes have recently attracted attention because they have been linked to many diseases including cancer [45]. In regard to histone modifications, no human or animal data are currently available and only few in vitro studies investigated these epigenetic effects [30-32]. Yoshida et al. [30] examined histone modifications in human lung adenocarcinoma epithelial A549 cells following an acute (10-600 $\mathrm{min}$ ) treatment with FA with a focus on histone 3 (H3). Treated cells showed greater levels of phosphorylated histone $\mathrm{H} 3$ at serine 10 (H3S10), and serine 28 (H3S28) residues compared with unexposed controls. Conversely, FA induced a reduction of the acetylation of histone $\mathrm{H} 3$ at lysine 9 (H3K9) and 14 (H3K14), and at the N-terminal site (H3 global) maybe in relation to the reaction that FA itself could have with lysine residues limiting acetylation. This mode of action was confirmed by the lack of acetylation reduction observed when histone was pre-acetylated before FA treatment, thus supporting the idea that FA could not react with acetylated lysine histone residues. Concerning the biological consequences of these epigenetic changes, the phosphorylation of $\mathrm{H} 3 \mathrm{~S} 10$ was enhanced at the promoter regions of the proto-oncogenes FOS and JUN. Both genes were dose-dependently induced by FA treatment suggesting a possible relationship between FA-induced tumor promotion activity and phosphorylation of H3S10. The biological responses induced by the alterations in histone acetylation remain to be understood. In line with these results, also the exposure of human pulmonary epithelial A549 cells, and normal human lung fibroblasts MRC-5 and WI-38 to cigarette side-stream smoke, containing FA, induced a significant phosphorylation of histone 3 at the serine 10 and 28 residues (H3S10, H3S28) [32]. As previously reported, such phosphorylation was increased in the promoter sites of the proto-oncogenes FOS and JUN, indicating a role of the cigarette smoke in tumor promotion. Since the phosphorylation of H3S10 was decreased in the aldehyde-removed cigarette side-stream smoke and was significantly induced by treatment with FA, aldehydes have been suspected to have partially contributed to this phenomenon.

Chen et al. [31] demonstrated FA's $(0.5 \mathrm{mM})$ ability to form adducts on lysine residues of histone proteins in human bronchial epithelial BEAS-2B cells. The formation of such FA-histone adducts prevented the acetylation of the same site by histone acetyltransferase as demonstrated by the dramatic decrease of the lysine acetylation of the cytosolic fraction of histones $\mathrm{H} 3$ and $\mathrm{H} 4$, specifically at $\mathrm{H} 3 \mathrm{~K} 9$, $\mathrm{H} 3 \mathrm{~K} 14$, and $\mathrm{H} 4 \mathrm{~K} 12$ residues. A comparable reduction in the acetylation of $\mathrm{H} 4 \mathrm{~K} 12$ residues was demonstrated with a lower concentration of FA $(100 \mu \mathrm{M})$ on the same cell line, but also on human osteosarcoma UTA6 and nasal epithelial RPMI2650 cells, although with different time periods of manifestation in the diverse cell lines. Such changes may affect chromatin accessibility to subsequent gene transcription. In fact, following FA exposure, the transport of histone $\mathrm{H} 3$ into chromatin is compromised affecting chromatin conformation and inducing transcriptional dysregulation. This was confirmed by the hundreds of genes whose expression was reported to be affected by $100-\mu \mathrm{M}$ exposure for $48 \mathrm{~h}$ in BEAS-2B cells. Among those, some tumor suppressors, i.e., CDKN1A and SERPINB5, and oncogenes, i.e., FOS and JUN, which were identified as potentially involved in head and neck cancer and/or in hematological neoplasias. Moreover, FA-induced inhibition of chromatin assembly may facilitate anchorage-independent growth of cells. Therefore, the ability of FA to compromise chromatin assembly through inhibition of lysine acetylation on newly synthesized histones represents a possible novel mechanism underlying FA-induced carcinogenesis.

The ability of FA to react with histone lysine residues reported by Yoshida et al. [30] and Chen et al. [31] are in line with previous results obtained by Lu et al. [45] in a simplified in vitro model 
employing $\mathrm{H} 4$ isolated from calf thymus tissues and human recombinant $\mathrm{H} 4$ purified after expression in E. Coli. The authors, in fact, demonstrated that the FA-induced lysine adducts on histone may impair post-transcriptional histone acetylation and deacetylation balance. This could affect the recruitment of specific proteins highly associated with the post-transcriptional pattern, and trigger a series of abnormal cascade effects responsible for alterations in normal cell growth.

\subsection{MicroRNAs}

MicroRNAs are small non-coding RNAs, of about 22 nucleotides, that regulate gene expression at the post-transcriptional level. The importance to investigate potential effects of FA on miRNAs relies on their ability to regulate gene expression through the binding of mRNA, causing rapid decay of the message, translational repression of the mRNA signals, and inducing cleavage of newly translated polypeptides [46]. Concerning in vivo responses induced by FA inhalation, the same group of researchers demonstrated a significant dysregulation in miRNA expression in the nose, olfactory bulb and white blood cells (WBCs) of rodents [35,36], as well as in the nasal epithelium cells of non-human primates [34]. Interestingly, Rager et al. [35] applied a multitiered approach to define possible genome-wide miRNA responses to FA, as well as time and tissue-related alterations in transcriptional profiles. MiRNA expression, in fact, was investigated within the nasal respiratory epithelium, circulating WBCs, and bone marrow (BM) and were affected in rats treated with FA via inhalation for 7 and 28 days [35]. The nose was the site with the greatest change in miRNA expression levels, followed by the WBCs, while no changes were evident in the BM samples. When alterations were analyzed according to the different 7 and 28 day exposures, FA-induced miRNA changes in nose showed high stability and no significant quantitative and qualitative differences over time. Such alterations failed to persist after a recovery period (7 days) following the 28-day treatment. Comparing the FA-responsive miRNAs across the different tissues revealed largely distinct miRNA responses, as only 10 alterations overlapped between nose and WBC samples and most with different directions of expression. Overall, these findings suggest that cells in direct contact with FA exposure are more responsive at the miRNA level than cells distant from exposure contact sites. Moreover, 7 of the 34 miRNAs with sustained decreased nose expression over time, i.e., let-7a, let-7c, let-7f, miR-10b, miR-126, miR-21, and miR-23a, have been previously shown to have decreased expression in cultured lung cells exposed to 1 ppm FA [33]. To integrate miRNA responses with transcriptional changes, mRNA profiles were assessed in the nose and WBCs. FA-responsive miRNAs were able to regulate a series of mRNAs, ranging from the $7 \%$ to $35 \%$ of those FA-related, determining an increase in immune system/inflammation signaling in both nose and WBCs.

Considering the miRNA alterations reported in nasal epithelium of treated rats, and the potential regulating role of miRNAs in the neurogenesis of the olfactory bulb, Li et al. [36] investigated expression changes within olfactory bulb in mice after FA acute to subacute inhalation. Eighteen miRNAs were upregulated and seven were down-regulated after an acute (6-h) exposure to FA via inhalation. In the olfactory bulb of mice exposed to FA, the alterations in miRNA expression was more profound after 1 day of exposure for $6 \mathrm{~h}$ relative to 7 days of $6 \mathrm{~h} /$ day of exposure, as this last condition only altered the expression of nine miRNAs. The differentially expressed miRNA, i.e., mir-141-5p, mir-200a-5p, mir-199b-5p, are believed to be involved in axon guidance and MAPK signaling, which are associated with inter-neuronal maturation in the bulb, essential to assure a normal olfactory function $[47,48]$. Additionally, also other pathways related to the immune system, such as toll-like receptor signaling and communication between innate and adaptive immune cells, molecular mechanisms of cancer, as well as cell cycle regulation have been also associated to the miRNA alterations detected after both 1and 7-days of exposure.

Potential changes in miRNA expression profiles have been also investigated in the nasal epithelial cells from the maxilla-turbinate region of Cynomolgus macaques, as the area with the maximum adsorption of FA, collected from animals treated via inhalation [34]. Microarray analysis identified three miRNAs with significantly decreased expression levels upon exposure to 2 ppm FA and 13 miRNAs with affected 
expression when exposure was to $6 \mathrm{ppm}$ (four significantly increased and nine significantly decreased). Interestingly, two of the 13 FA-responsive miRNAs were among those reported as affected in vitro by FA, namely miR-26b and miR-140-5p [33]. The two most increased (miR-125b and miR-152) and decreased (miR-145 and miR-142-3p) miRNAs in response to 6 ppm FA were primarily correlated with pathways involved in sphingolipid metabolism, apoptosis, and ILK signaling. Concerning sphingolipids, recent work has demonstrated that their metabolites are involved in the regulatory signaling of various biological processes, including apoptosis, cell cycle arrest, inflammation, necrosis, and senescence [49]. The epigenetic FA-mediated control on apoptotic mechanisms that may be associated with cellular transformation and cancer development could be demonstrated by the decreased expression of four apoptosis-related mRNAs predicted to be regulated by miR-125b. ILK signaling is involved in a variety of processes within epithelial cells, including cell survival, cell proliferation, and cell adhesion to the extracellular matrix [50]. Additionally, many other FA-responsive miRNAs have known relationship with cancers, and particularly were differentially expressed in human nasopharyngeal carcinomas. These effects demonstrate the FA ability to significantly disrupt miRNA expression profiles within the nasal epithelium that may influence cellular disease state.

The expression levels of miRNAs have been demonstrated to be dysregulated by FA exposure in vitro [33]. In particular, when A549 type II lung human carcinoma epithelial cells were acutely treated with gaseous FA, using a direct air-liquid interface that physically mimics the human respiratory tract, microarray analysis demonstrated that 89 miRNAs were significantly down-regulated compared to untreated controls, while no significant increased expression could be detected. Functional and molecular network analysis of the predicted miRNA transcript targets revealed that FA exposure altered the signaling pathways associated with cellular growth/development and proliferation. Moreover, as a confirmation that FA treatment could activate inflammatory response, IL-8 pathway was demonstrated to be increased by FA-miRNA-induced alterations, with increased protein expression levels compared to controls.

\section{Discussion}

The general living and occupational ubiquitous nature of exposure to FA requires a deep understanding of the molecular mechanisms potentially underlying its induced toxicity and carcinogenicity. In this regard, although the limited number of studies and the lack of robust epidemiological data on occupational exposed populations still prevent the extrapolation of definite conclusions, preliminary evidences are emerging concerning the possibility that epigenetic changes may condition biological response to FA.

Workers exposed to FA demonstrated a global increase in DNA methylation in whole blood samples, positively related to FA workplace levels, to the number of procedures involving such chemical exposure, as well as to have been directly employed in such specific job tasks [28]. Conflicting evidence in DNA methylation emerged when these human findings were compared with previously published in vitro results. In fact, these reported a significant decrease in global methylation in bronchial epithelial cells chronically treated with FA, or the absence of significant DNA methylation changes in acutely exposed human lymphoblastoid cells [29,32]. This may be due to the different biological matrices investigated, i.e., the whole blood in humans [28] vs. bronchial and lymphoblastoid cells in the experimental in vitro settings [29,32], which may be biased by cell-specific methylation patterns. Variable experimental designs, i.e., concerning doses and time periods of FA exposure, as well as the diverse analytical techniques adopted, i.e., high-performance liquid chromatography-diode array detector equipment [28], high-performance capillary electrophoresis assay [29], and tandem mass spectrometry [32], may all be responsible for quite different results. In this scenario, to define the role of DNA methylation changes as possible FA biomarkers of early effect, future in-field and epidemiological investigations seem absolutely necessary.

However, although in vitro experimental settings may provide a limited representativeness of real human exposure contexts, such investigations may contribute to identify target genes whose 
expression changes may be involved in FA-induced methylation effects and toxic manifestations. This idea is supported by the specific patterns of DNMT1, DNMT3a, DNMT3b expression responses found in human bronchial epithelial cells that may suggest specific FA-induced alterations, in turn reflecting the methylation levels determined in the samples [42]. Such data, once confirmed in epidemiological investigations, may provide further support to the role of such specific patterns of changes as possible FA biomarkers of early effect to be considered in suitable risk assessment processes.

Scientific evidence has been emerging concerning the role of histone post-translational modifications in a multitude of DNA related processes, such as DNA damage repair, DNA replication, and transcription of tumor-related genes [51,52]. In particular, the dysregulation of histone $\mathrm{H} 3$ phosphorylation, reported following FA exposure, may perturb cellular pathways involved in human cancer development [30,32]. In fact, it is known that in interphase cells, such phosphorylation phenomena are involved in the chromatin remodeling of the promoter regions of specific loci, i.e., FOS and JUN, implicated in tumorigenic processes, while in mitotic cells, they are responsible for the maintaining of chromosome stability and their accurate segregation [53]. Histone H3 phosphorylation was reported in aflatoxin B1-transformed hepatocytes, benzo(a)pyrene- and coke oven emissions-transformed human bronchial epithelial cells in which such modification performed a mediation role in cellular carcinogenic transformation [51]. The phosphorylation of H3S10 has been reported also to be induced by several environmental factors, such as arsenite [54], nickel [55], and UVB [56,57].

Histone modification changes induced by FA exposure, included also the formation of FA-lysine histone adducts and the consequent reduction in lysine acetylation. In general, acetylation neutralizes the positive charge of lysine residues, resulting in a weaker histone-DNA interaction, in a subsequent relaxation of the chromatin, and transcriptional activation [58]. In this context, FA may impact post-transcriptional modifications disturbing the recruitment of regulatory complexes and evolving into an aberrant chromatin assembly that may facilitate anchorage-independent growth of cells. These data suggest that compromising chromatin assembly, through inhibition of lysine acetylation, may dysregulate cancer-related gene expression, as a possible new mechanism underlying FA-induced carcinogenesis [31]. The identification of FA reactive sites on histones is an initial step in understanding additional mechanisms of FA toxicity and carcinogenicity [59]. However, many issues remain to be clarified concerning the structure and fate of FA lysine adducts, the biological impact of such modifications on lysine residues, which are the exact sites for the formation of adducts, and their exact modes of action as well as how these changes may be recovered. Overall, to fully understand these aspects may be important to define the role of such alterations as possible biomarkers of early effect or susceptibility to the adverse FA impact.

MicroRNA alterations have been detected in both in vitro [33] and in vivo models [34-36]. From a biological monitoring perspective, some conclusions, emerged from the study by Rager et al. [35], need to be carefully considered. In different, simultaneously analyzed tissues, in fact, the authors determined the greatest and more time-stable miRNA alterations (from 7 to 28 days of treatment) in the "most directly exposed" nose epithelium compared to the "less directly exposed" WBCs. Moreover, miRNA changes showed a tissue-specific expression as only a minimal part of the alterations overlapped between these two different target sites. This underlines the importance to preliminary evaluate the relevance of individual biological matrices in the assessment of epigenetic biomarkers in relation to the routes of exposure as well as to the biological cascade intended to be investigated. Most of the miRNAs affected in nose epithelium and WBCs, in fact, were related to the expression of genes involved in nasopharyngeal carcinomas as well as in inflammatory/immune responses. Comparably, miRNA alterations detected in nose-epithelium of nonhuman primates were predicted to affect the balance between cell death and survival-affecting apoptosis, cell cycle progression, inflammation, therefore being potentially implicated in cellular transformation and cancer development [34,36].

Then, an altered expression of miRNAs may not only be useful as a biomarker, but also as an active component or tumor development. Evidence has been pointed out concerning the miRNA 
alterations in all types of human cancer, both induced by genotoxic carcinogens, i.e., polycyclic aromatic hydrocarbon, aflatoxin B1, n-nitroso compounds, as well as by not genotoxic carcinogens, i.e., arsenic [27]. However, the specific role of miRNA deregulation in the etiology of cancers remain to be elucidated. To establish a link between miRNAs and carcinogenesis, some essential issues need to be addressed, such as if the altered expression of miRNA occurs at the early stages of carcinogenesis in the target organ and if such early changes are also evident in full-fledged tumors; if a mechanistic link exists between aberrant miRNA expression and cancer development; and whether altered miRNA expression is sufficient to initiate neoplastic cell transformation and cancer development.

Interestingly, it was estimated that between $7 \%$ and $35 \%$ of the FA-responsive transcripts were regulated by FA-associated miRNAs. These data, on the one side, suggest that the miRNAs may be operating through mechanisms other than mRNA degradation $[46,60]$, but also that, on the other side, other transcriptional regulators, such as DNA methylation and histone modifications [61], may play a role in FA-induced genomic responses. It may be argued that, DNMTs may cooperate with histone modifying enzymes to repress specific gene region expression, conversely, histone modifications may impact DNA methylation patterns, and also a bidirectional influence between miRNA and DNA methylation can exist [42]. Therefore, to assess the relevance of epigenetic effects in biological monitoring will require further research comprehensive of a deep analysis of all the three principal mechanisms and their possible interplay.

Finally, some limitations emerged from our revision that should be pointed out in order to plan future methodologically adequate investigations able to provide more informative data. The availability of only one study on occupationally FA-exposed subjects, underlines the relevance to plan in-field, and epidemiological investigations to define the role of epigenetic changes as possible biomarkers of early FA effects on humans. Although in vitro and in vivo studies, may be important to extrapolate preliminary information, caution should be applied to adequately interpret results obtained with high-doses of exposure (i.e., up to 6 ppm FA in vivo, almost greater than concentrations found in workplace settings) $[3,12]$ and for periods of treatment not resembling those experienced by occupationally FA-involved populations (i.e., maximum 28 days in vivo) [34-36]. Future investigations should confirm epigenetic effects following experimental conditions better resembling those realistically occurring in workplace settings, generally characterized by low-dose, long-term exposures. This seems even more important considering that some changes in DNA methylation have been determined in subjects exposed at levels lower than those commonly adopted as occupational exposure limits. Longitudinal studies are also strongly pursued. Diverse miRNA modifications, in fact, were evident after shorter acute or subacute exposures compared to longer ones, suggesting that variable duration of treatment may differently affect target biological responses and therefore biological monitoring findings [35,36]. A deeper research, aimed to overcome such knowledge gaps, may be useful to understand the relevance of epigenetic early biological alterations in risk assessment and management remodeling in public and occupational exposure settings which may include also the re-assessment of currently available occupational exposure limits to better protect the health of involved workers.

\section{Conclusions}

Epigenetics may provide a useful tool to understand the molecular mechanisms underlying FA toxicological profile and to point out the relationship between FA chemical exposure, genome/epigenome changes, and disease risk. Although preliminary evidence demonstrated DNA methylation, histone and miRNA changes may be induced by FA exposure in workers, as well as in in vivo and in vitro experimental settings; the limited number of available studies prevent definite conclusions. Therefore, in vivo and in vitro studies, performed under conditions better resembling those experienced in occupational and general living environments, may provide data on qualitative and quantitative epigenetic changes as well as proper biological matrices to be analyzed and time-dependent trends to be verified in human biological monitoring investigations. This kind of research may further contribute to the understanding of new mechanisms underlying FA-induced 
toxicity, and particularly, carcinogenicity. Finally, in-field and epidemiological investigations should be pursued to confirm such experimental results and define their possible role as FA early biological effect indicators. More definite, future knowledge on this topic may allow to include epigenetic information in suitable risk assessment and management processes to assure a better protection of the health of public and occupationally FA-exposed populations.

Author Contributions: Conceptualization, V.L., I.I.; methodology, V.L., M.C.M., F.R.; writing—original draft preparation, V.L., M.C.M., F.R.; writing—review and editing, V.L. and I.I.; supervision, V.L., I.I. All authors have read and agreed to the published version of the manuscript.

Funding: This research received no external funding.

Conflicts of Interest: The authors declare no conflict of interest.

\section{References}

1. Salthammer, T.; Mentese, S.; Marutzky, R. Formaldehyde in the indoor environment. Chem. Rev. 2010, 110, 2536-2572. [CrossRef]

2. World Health Organization (WHO). WHO guidelines for indoor air quality: Selected pollutants. WHO Guide 2010, 9, 454 .

3. IARC, Working Group on the Evaluation of Carcinogenic Risks to Humans Chemical Agents and Related Occupations. Formaldehyde. IARC Monogr. Eval. Carcinog. Risks Hum. 2012, 100, 9-562.

4. National Toxicology Program (NTP). NTP 12th report on carcinogens. Rep. Carcinog. Carcinog. Profiles 2011, 12, iii-499.

5. WHO Regional Office for Europe Copenhagen. Formaldehyde. In Air Quality Guidelines for Europe-Second Edition; 2000; chapter 5.8; pp. 87-91. Available online: http://www.euro.who.int/_data/assets/pdf_file/0005/ 74732/E71922.pdf (accessed on 26 March 2020).

6. Godish, T. Formaldehyde exposures from tobacco smoke: A review. Am. J. Public Health 1989, 79, 1044-1045. [CrossRef] [PubMed]

7. Dahl, A.R.; Hadley, W.M. Formaldehyde production promoted by rat nasal cytochrome P-450-dependent monooxygenases with nasal decongestants, essences, solvents, air pollutants, nicotine, and cocaine as substrates. Toxicol. Appl. Pharmacol. 1983, 67, 200-205. [CrossRef]

8. Yang, M.; Ospina, M.; Tse, C.; Toth, S.; Caudill, S.P.; Vesper, H.W. Ultraperformance liquid chromatography tandem mass spectrometry method to determine formaldehyde hemoglobin adducts in humans as biomarker for formaldehyde exposure. Chem. Res. Toxicol. 2017, 30, 1592-1598. [CrossRef]

9. Liteplo, R.G.; Meek, M.E. Inhaled formaldehyde: Exposure estimation, hazard characterization, and exposure-response analysis. J. Toxicol. Environ. Health B Crit. Rev. 2003, 6, 85-114. [CrossRef] [PubMed]

10. IARC, Working Group on the Evaluation of Carcinogenic Risks to Humans Chemical Agents and Related Occupations. Formaldehyde, 2-butoxyethanol and 1-tertbutoxypropan-2-ol. IARC Monogr. Eval. Carcinog. Risks Hum. 2006, 88, 1-478.

11. Schmid, O.; Speit, G. Genotoxic effects induced by formaldehyde in human blood and implications for the interpretation of biomonitoring studies. Mutagenesis 2007, 22, 69-74. [CrossRef]

12. Orsière, T.; Sari-Minodier, I.; Iarmarcovai, G.; Botta, A. Genotoxic risk assessment of pathology and anatomy laboratory workers exposed to formaldehyde by use of personal air sampling and analysis of DNA damage in peripheral lymphocytes. Mutat. Res. 2006, 605, 30-41. [CrossRef] [PubMed]

13. Ye, X.; Yan, W.; Xie, H.; Zhao, M.; Ying, C. Cytogenetic analysis of nasal mucosa cells and lymphocytes from high level long-term formaldehyde exposed workers and low-level short-term exposed waiters. Mutat. Res. 2005, 588, 22-27. [CrossRef] [PubMed]

14. Edrissi, B.; Taghizadeh, K.; Dedon, P.C. Quantitative analysis of histone modifications: Formaldehyde is a source of pathological n-formyllysine that is refractory to histone deacetylases. PLoS Genet. 2013, 9, e1003328. [CrossRef] [PubMed] 
15. Edrissi, B.; Taghizadeh, K.; Moeller, B.C.; Kracko, D.; Doyle-Eisele, M.; Swenberg, J.A.; Dedon, P.C. Dosimetry of $\mathrm{N}$-formyllysine adducts following [C H]-formaldehyde exposures in rats. Chem. Res. Toxicol. 2013, 26, 1421-1423. [CrossRef] [PubMed]

16. Bogdanffy, M.S.; Morgan, P.H.; Starr, T.B.; Morgan, K.T. Binding of formaldehyde to human and rat nasal mucus and bovine serum albumin. Toxicol. Lett. 1987, 38, 145-154. [CrossRef]

17. Metz, B.; Kersten, G.F.; Baart, G.J.; de Jong, A.; Meiring, H.; ten Hove, J.; van Steenbergen, M.J.; Hennink, W.E.; Crommelin, D.J.; Jiskoot, W. Identification of formaldehyde-induced modifications in proteins: Reactions with insulin. Bioconjugate Chem. 2006, 17, 815-822. [CrossRef]

18. Guthe, K.F. The formaldehyde-hemoglobin reaction. J. Biol. Chem. 1959, 234, 3169-3173.

19. Hoberman, H.D.; San George, R.C. Reaction of tobacco smoke aldehydes with human hemoglobin. J. Biochem. Toxicol. 1989, 3, 105-119. [CrossRef]

20. Swenberg, J.A.; Lu, K.; Moeller, B.C.; Gao, L.; Upton, P.B.; Nakamura, J.; Starr, T.B. Endogenous versus exogenous DNA adducts: Their role in carcinogenesis, epidemiology, and risk assessment. Toxicol. Sci. 2011, 120 (Suppl. 1), S130-S145. [CrossRef]

21. Tabish, A.M.; Poels, K.; Hoet, P.; Godderis, L. Epigenetic factors in cancer risk: Effect of chemical carcinogens on global DNA methylation pattern in human TK6 cells. PLoS ONE 2012, 7, e34674. [CrossRef]

22. Swenberg, J.A.; Moeller, B.C.; Lu, K.; Rager, J.E.; Fry, R.C.; Starr, T.B. Formaldehyde carcinogenicity research: 30 years and counting for mode of action, epidemiology, and cancer risk assessment. Toxicol. Pathol. 2013, 41, 181-189. [CrossRef] [PubMed]

23. Egger, G.; Liang, G.; Aparicio, A.; Jones, P.A. Epigenetics in human disease and prospects for epigenetic therapy. Nature 2004, 429, 457-463. [CrossRef] [PubMed]

24. Arimondo, P.B.; Barberousse, A.; Pontarotti, G. The Many Faces of Epigenetics Oxford, December 2017. Epigenetics 2019, 14, 623-631. [CrossRef] [PubMed]

25. Feinberg, A. The key role of epigenetics in human disease. N. Engl. J. Med. 2018, 379, 400-401.

26. Karpinets, T.V.; Foy, B.D. Tumorigenesis: The adaptation of mammalian cells to sustained stress environment by epigenetic alterations and succeeding matched mutations. Carcinogenesis 2005, 26, 1323-1334. [CrossRef]

27. Pogribny, I.P.; Muskhelishvili, L.; Tryndyak, V.P.; Beland, F.A. The role of epigenetic events in genotoxic hepatocarcinogenesis induced by 2-acetylaminofluorene. Mutat. Res. 2011, 722, 106-113. [CrossRef]

28. Barbosa, E.; Dos Santos, A.L.A.; Peteffi, G.P.; Schneider, A.; Müller, D.; Rovaris, D.; Bau, C.H.D.; Linden, R.; Antunes, M.V.; Charão, M.F. Increase of global DNA methylation patterns in beauty salon workers exposed to low levels of formaldehyde. Environ. Sci Pollut. Res. Int. 2019, 26, 1304-1314. [CrossRef]

29. Liu, Q.; Yang, L.; Gong, C.; Tao, G.; Huang, H.; Liu, J.; Zhang, H.; Wu, D.; Xia, B.; Hu, G.; et al. Effects of long-term low-dose formaldehyde exposure on global genomic hypomethylation in 16HBE cells. Toxicol. Lett. 2011, 205, 235-240. [CrossRef]

30. Yoshida, I.; Ibuki, Y. Formaldehyde-induced histone H3 phosphorylation via JNK and the expression of proto-oncogenes. Mutat. Res. 2014, 770, 9-18. [CrossRef]

31. Chen, D.; Fang, L.; Mei, S.; Li, H.; Xu, X.; Des Marais, T.L.; Lu, K.; Liu, X.S.; Jin, C. Regulation of Chromatin Assembly and Cell Transformation by Formaldehyde Exposure in Human Cells. Environ. Health Perspect. 2017, 125, 097019. [CrossRef]

32. Ibuki, Y.; Toyooka, T.; Zhao, X.; Yoshida, I. Cigarette sidestream smoke induces histone H3 phosphorylation via JNK and PI3K/Akt pathways, leading to the expression of proto-oncogenes. Carcinogenesis 2014, 35, 1228-1237. [CrossRef] [PubMed]

33. Rager, J.E.; Smeester, L.; Jaspers, I.; Sexton, K.G.; Fry, R.C. Epigenetic changes induced by air toxics: Formaldehyde exposure alters miRNA expression profiles in human lung cells. Environ. Health Perspect. 2011, 119, 494-500. [CrossRef] [PubMed]

34. Rager, J.E.; Moeller, B.C.; Doyle-Eisele, M.; Kracko, D.; Swenberg, J.A.; Fry, R.C. Formaldehyde and epigenetic alterations: microRna changes in the nasal epithelium of nonhuman primates. Environ. Health Perspect. 2013, 121, 339-344. [CrossRef] [PubMed]

35. Rager, J.E.; Moeller, B.C.; Miller, S.K.; Kracko, D.; Doyle-Eisele, M.; Swenberg, J.A.; Fry, R.C. Formaldehyde-associated changes in microRNAs: Tissue and temporal specificity in the rat nose, white blood cells, and bone marrow. Toxicol. Sci. 2014, 138, 36-46. [CrossRef] [PubMed] 
36. Li, G.; Yang, J.; Ling, S. Formaldehyde exposure alters miRNA expression profiles in the olfactory bulb. Inhal. Toxicol. 2015, 27, 387-393. [CrossRef] [PubMed]

37. Esteller, M. Relevance of DNA methylation in the management of cancer. Lancet Oncol. 2003, 4, 351-358. [CrossRef]

38. Pierce, J.S.; Abelmann, A.; Spicer, L.J.; Adams, R.E.; Glynn, M.E.; Neier, K.; Finley, B.L.; Gaffney, S.H. Characterization of formaldehyde exposure resulting from the use of four professional hair straightening products. J. Occup. Environ. Hyg. 2011, 8, 686-699. [CrossRef]

39. Norma Regulamentadora 15 (NR 15). Atividades e operações insalubres. D.O.U. Portaria MTb 1978, 3, 214.

40. OSHA, Occupational Safety and Health Administration. Formaldehyde. Available online: https://www.osha. gov/OshDoc/data_General_Facts/formaldehyde-factsheet.pdf (accessed on 25 November 2019).

41. ECHA, European Chemicals Agency. Worker Exposure to Formaldehyde and Formaldehyde Releasers. 2019. Available online: https://echa.europa.eu/documents/10162/13641/investigationreport_formaldehyde_ workers-exposure_final_en.pdf/ac457a0c-378d-4eae-c602-c7cd59abc4c5 (accessed on 19 March 2020).

42. Moore, L.D.; Le, T.; Fan, G. DNA methylation and its basic function. Neuropsychopharmacology 2013, 38, $23-38$. [CrossRef]

43. Chappell, G.; Pogribny, I.P.; Guyton, K.Z.; Rusyn, I. Epigenetic alterations induced by genotoxic occupational and environmental human chemical carcinogens: A systematic literature review. Mutat. Res. Rev. Mutat. Res. 2016, 768, 27-45. [CrossRef]

44. Weber, D.; Heisig, J.; Kneitz, S.; Wolf, E.; Eilers, M.; Gessler, M. Mechanisms of epigenetic and cell-type specific regulation of Hey target genes in ES cells and cardiomyocytes. J. Mol. Cell. Cardiol. 2015, 79, 79-88. [CrossRef] [PubMed]

45. Lu, K.; Boysen, G.; Gao, L.; Collins, L.B.; Swenberg, J.A. Formaldehyde-induced histone modifications in vitro. Chem. Res. Toxicol. 2008, 21, 1586-1593. [CrossRef] [PubMed]

46. Filipowicz, W.; Bhattacharyya, S.N.; Sonenberg, N. Mechanisms of post-transcriptional regulation by microRNAs: Are the answers in sight? Nat. Rev. Genet. 2008, 9, 102-114. [CrossRef] [PubMed]

47. Choi, P.S.; Zakhary, L.; Choi, W.Y.; Caron, S.; Alvarez-Saavedra, E.; Miska, E.A.; McManus, M.; Harfe, B.; Giraldez, A.J.; Horvitz, H.R.; et al. Members of the miRNA-200 family regulate olfactory neurogenesis. Neuron 2008, 57, 41-55. [CrossRef] [PubMed]

48. Imai, T.; Sakano, H. Axon-axon interactions in neuronal circuit assembly: Lessons from olfactory map formation. Eur. J. Neurosci. 2011, 34, 1647-1654. [CrossRef] [PubMed]

49. Bartke, N.; Hannun, Y.A. Bioactive sphingolipids: Metabolism and function. J. Lipid Res. 2009, 50, S91-S96. [CrossRef]

50. Gilcrease, M.Z. Integrin signaling in epithelial cells. Cancer Lett. 2007, 247, 1-25. [CrossRef]

51. Zhu, X.; Li, D.; Zhang, Z.; Zhu, W.; Li, W.; Zhao, J.; Xing, X.; He, Z.; Wang, S.; Wang, F.; et al. Persistent phosphorylation at specific $\mathrm{H} 3$ serine residues involved in chemical carcinogen-induced cell transformation. Mol. Carcinog. 2017, 56, 1449-1460. [CrossRef]

52. Faucher, D.; Wellinger, R.J. Methylated H3K4, a transcription associated histone modification, is involved in the DNA damage response pathway. PLoS Genet. 2010, 6, e1001082. [CrossRef]

53. Thompson, L.L.; Guppy, B.J.; Sawchuk, L.; Davie, J.R.; McManus, K.J. Regulation of chromatin structure via histone post-translational modification and the link to carcinogenesis. Cancer Metastasis Rev. 2013, 32, 363-376. [CrossRef]

54. Li, J.; Gorospe, M.; Barnes, J.; Liu, Y. Tumor promoter arsenite stimulates histone H3 phosphoacetylation of proto-oncogenes c-fos and c-jun chromatin in human diploid fibroblasts. J. Biol. Chem. 2003, 278, 13183-13191. [CrossRef] [PubMed]

55. Ke, Q.; Li, Q.; Ellen, T.P.; Sun, H.; Costa, M. Nickel compounds induce phosphorylation of histone H3 at serine 10 by activating JNK-MAPK pathway. Carcinogenesis 2008, 29, 1276-1281. [CrossRef] [PubMed]

56. Keum, Y.S.; Kim, H.G.; Bode, A.M.; Surh, Y.J.; Dong, Z. UVB-induced COX-2 expression requires histone H3 phosphorylation at Ser10 and Ser28. Oncogene 2013, 32, 444-452. [CrossRef] [PubMed]

57. He, Z.; Cho, Y.Y.; Ma, W.Y.; Choi, H.S.; Bode, A.M.; Dong, Z. Regulation of ultraviolet B-induced phosphorylation of histone H3 at serine 10 by Fyn kinase. J. Biol. Chem. 2005, 280, 2446-2454. [CrossRef]

58. Banister, C.E.; Koestler, D.C.; Maccani, M.A.; Padbury, J.F.; Houseman, E.A.; Marsit, C.J. Infant growth restriction is associated with distinct patterns of DNA methylation in human placentas. Epigenetics 2011, 6, 920-927. [CrossRef] 
59. Ransom, M.; Dennehey, B.K.; Tyler, J.K. Chaperoning histones during DNA replication and repair. Cell 2010, 140, 183-195. [CrossRef]

60. Bailey, K.A.; Fry, R.C. Environmental toxicants and perturbation of miRNA signaling. In microRNAs in Toxicology and Medicine; Sahu, S.C., Ed.; John Wiley \& Sons, Ltd.: Chichester, UK, 2013.

61. Cedar, H.; Bergman, Y. Linking DNA methylation and histone modification: Patterns and paradigms. Nat. Rev. Genet. 2009, 10, 295-304. [CrossRef]

(C) 2020 by the authors. Licensee MDPI, Basel, Switzerland. This article is an open access article distributed under the terms and conditions of the Creative Commons Attribution (CC BY) license (http://creativecommons.org/licenses/by/4.0/). 